\title{
SIK2 Gene
}

National Cancer Institute

\section{Source}

National Cancer Institute. SIK2 Gene. NCI Thesaurus. Code C92518.

This gene plays a role in both signal transduction and spindle formation. 